Kazimierz Serwin

\title{
Percepcja traktatu triańskiego/trianońskiego w węgierskiej kulturze
}

\begin{abstract}
Wstęp
Hasło „Trianon” jest chyba najbardziej znanym pojęciem historycznym na Węgrzech. Dnia 4 VI 1920 r. w pałacu Grand Trianon w Wersalu narzucono Węgrom restrykcyjne warunki pokojowe. W węgierskiej świadomości historycznej Traktat z Trianon jest symbolem katastrofy i narodowego upokorzenia. Zmianą „Wielkich Węgier” w Węgry „okrojone”.
\end{abstract}

\section{Konsekwencje przegranej wojny i rozpadu Austro-Węgier}

Zmniejszenie powierzchni Węgier, a co zatem idzie liczby ludności, miało jednak miejsce jeszcze przed samym podpisaniem traktatu, tj. na przełomie 1918 i 1919 r. W grudniu 1918 r. żołnierze rumuńscy zajęli Koloszowar. Natomiast w styczniu wojska czechosłowackie objęły władzę w Preszburgu (późniejsza Bratysława) i Koszycach. Z kolei Nowy Sad i Szabadka (obecnie oba miasta w Serbii) trafiły w ręce Słowian południowych pod władzą Serbów. Zwycięskie mocarstwa dały praktycznie wolną rękę nacjonalizmom: serbskiemu, rumuńskiemu i „czechosłowackiemu”, które znalazły się po stronie państw Ententy. Niewątpliwie przedstawiciele państw powstałych z rozpadu Monarchii starały się zająć te terytoria, które chcieli uzyskać, dlatego do stycznia 1919 r. armia czechosłowacka znalazła się na linii Bratysława-Komarno-Ipolyság-Rimaszombat-Koszyce, a Jugosłowianie w listopadzie 1918 r. dotarli do przyznanych im później terenów, wykraczając także poza nie ${ }^{1}$. Równocześnie na konferencji pokojowej w Paryżu, obradującej od 18 I 1919 r., delegacje czechosłowacka, rumuńska i serbsko-chorwacko-słoweńska, powołując się jednomyślnie na wielowiekowy ucisk ze strony Węgrów, domagały się oswobodzenia ziem zamieszkanych przez swych rodaków.

B. Ablonczy, Po stu latach, https://kurier.plus/node/1427 (4 VI 2020). 
Wysunęły także żądania terytorialne, które znacznie wykraczały poza obszar zakreślony granicami etnicznymi. Po przegranej wojnie nie było szans na pozostawienie w nienaruszonym stanie granic historycznego Królestwa Węgier, choć podjęto rozmowy z mniejszościami etnicznymi na temat współpracy w ramach jednego państwa.

Pomimo działań wspomnianych nacji po 1920 r. na kształt granic Węgier decydujący wpływ miały przede wszystkim zwycięskie mocarstwa, w szczególności Francja. Paryska konferencja zadekretowała powstanie neutralnej strefy pomiędzy wojskami węgierskimi i rumuńskimi. To posunięcie było projekcją późniejszej granicy trianońskiej. W związku z tym rząd Károlyiego (premier i prezydent Węgier w latach 1918-1919) musiał podać się do dymisji i przekazać władzę socjaldemokratom, którzy ostatecznie związali się z komunistami.

Dojście do władzy komunistycznej Republiki Rad 21 III 1919 r. było również spowodowane polityką Francji, która wspierała żądania małych państw. Jako przyczynę przejęcia władzy przez bolszewików podaje się urażoną dumę narodową. Sándor Garbai, jeden z najbardziej poważanych socjaldemokratycznych liderów robotniczych, informował o umowie zjednoczeniowej socjaldemokratów i komunistów oraz nadziei na sojusz z bolszewickim państwem Lenina. „To nasza jedyna droga” - oznajmił. „Chcemy dostać od Wschodu to, czego nie dostaliśmy od Zachodu".

Prawdopodobnie antybolszewizm uczestników konferencji spowodował, że większość propozycji dotyczących modyfikacji granic była na niekorzyść Węgier (region Mura, Węgry Zachodnie). Po upadku Republiki Rad Ententa zaprosiła przedstawicieli rządu Károlya Huszára na konferencję pokojową w grudniu 1919 r. Był to pierwszy węgierski rząd między listopadem 1918 r. a grudniem 1919 r., który uznała Ententa. Kiedy węgierska delegacja pokojowa, kierowana przez Alberta Apponyiego, przybyła do Paryża 7 I 1920 r. było już za późno, aby zastopować zmiany, bo wiele spraw na konferencji zostało zamkniętych ze szkodą dla Węgier.

Ostatecznie traktat został podpisany 4 VI 1920 r. w pałacu Grand Trianon między Węgrami a państwami Ententy: Stanami Zjednoczonym (które go nigdy nie ratyfikowały), Wielką Brytanią, Francją, Włochami, Japonią, Rumunią, Królestwem SHS (późniejsza Jugosławia), Czechosłowacją i Polską (która go również nie ratyfikowała). Hr. Albert Apponyi w całości odrzucił projekt traktatu, stwierdzając, że Węgry w stosunku do nieznacznej odpowiedzialności, jaką ponosiły za wojnę, zostaną ukarane niewspółmiernie do czynu, a w sposób „zagrażający wręcz ich bytowi”. Apponyi zaprzeczył, że Węgry prowadziły politykę represji wobec mniejszości narodowych, które „obecnie w większości znajdują się na niższym poziomie kulturowym". Ostatecznie ze strony węgierskiej porozumienie podpisali minister zdrowia i ambasador w Paryżu, którzy zaraz potem zrezygnowali ze stanowisk i wycofali się z życia publicznego. 
Na mocy traktatu Węgry utraciły niemal dwie trzecie ludności (pozostało 8 z 21 milionów) oraz dwie trzecie obszaru państwa (pozostało 93 tys. $\mathrm{km}^{2}$ z 325 tys. $\mathrm{km}^{2}$ ), łącznie z dostępem do morza. Co jednak najistotniejsze, poza granicami kraju znalazło się 3,5 miliona Węgrów, głównie w południowej Słowacji i siedmiogrodzkim Seklerlandzie oraz części Wojwodiny. 1/3 Węgrów znalazła się w sytuacji mniejszości narodowej.

Zgodnie z traktatem trianońskim Węgry uznały niepodległość Czechosłowacji oraz Królestwa Serbów, Chorwatów i Słoweńców. Z terenów dawnych Węgier Rumunia uzyskała Siedmiogród oraz część Kriszany, Marmaroszu i Banatu oraz kilka mniejszych krain, z kolei Czechosłowacja zajęła tereny obecnej Słowacji (dawne Górne Węrry) i Ruś Zakarpacką, natomiast Królestwo SHS otrzymało: Chorwację, Bośnię, Hercegowinę, większość Baczki oraz część Banatu. Nawet Austria, spadkobierca monarchii, uzyskała zachodnie części komitatów (jednostka administracyjna pierwszego rzędu w podziale administracyjnym Węgier oraz Chorwacji, odpowiadająca polskiemu województwu) - Sopron, Moson i Vas, z których powstał Burgenland.

Węgry uznały także ewentualne decyzje dotyczące granic kilku innych państw (w tym Polski), jakie mogłyby być podjęte w przyszłości przez mocarstwa sprzymierzone. Znalazło to zastosowanie 28 VII 1920 r., kiedy Rada Ambasadorów podzieliła należące przedtem do Węgier tereny Spisza i Orawy między Polskę i Czechosłowację.

Zgodnie z traktatem liczebność armii nie mogła przekraczać 35 tys. Węgrzy nie mogli mieć lotnictwa i marynarki wojennej, rozwijać przemysłu zbrojeniowego, budować linii kolejowych innych niż jednotorowe. Do tego doszły też reparacje wojenne ${ }^{2}$.

\section{Mniejszości narodowe na Węgrzech}

Traktat z olbrzyma robiący karła nie mógł nie wpłynąć na stan ducha Węgrów i ich kulturę. Przed wojną w granicach Węgier leżały tereny od Tatr po porty nad Adriatykiem, tyle że z wieloma mniejszościami etnicznymi. Niewątpliwie dzięki Unii z Austrią Węgry zyskały nie tylko terytorialnie, ale też gospodarczo. Pomiędzy rokiem 1867 a 1913 PKB wzrósł z 2,4 do 8,1 mld koron, a produkt krajowy brutto przypadający na jednego mieszkańca - ze 176 do 435 koron. Średnioroczne tempo wzrostu PKB na poziomie 2,7\% wyróżniało się na tle wyników osiąganych wówczas w Europie ${ }^{3}$.

M. Zeidler, Traktat pokojowy w Trianon $z 1920$ r., „W sieci historii” 2020, nr 5-6, s. 51-54.

I. Bertenyi jr, Monarchia Austro-Węgierska, „W sieci historii” 2020, nr 5-6, s. 44-48. 
Skok cywilizacyjny miał miejsce przede wszystkim w niektórych ośrodkach, głównie w stającym się metropolią Budapeszcie. Oprócz niego rozkwit przeżywało kilka ważnych miast na prowincji: Temeszwar, Arad, Wielki Waradyn, Koloszwar (obecnie wszystkie w Rumunii), Preszburg, Koszyce (oba miasta na Słowacji), Szeged, Gyor. Natomiast mieszkańcy wsi znacznie mniej skorzystali na modernizacji. Beneficjentami zostali mieszkańcy lepiej rozwiniętych obszarów w środkowej i południowej części kraju, głównie Węgrzy, a w mniejszym zaś stopniu 10-procentowa mniejszość niemiecka czy 4-procentowa mniejszość Słowian południowych, głównie serbska. Natomiast znaczna część mniejszości, które wraz z Niemcami i Słowianami południowymi stanowiły prawie połowę ludności kraju (16-procentowa mniejszość rumuńska, 11-procentowa słowacka wraz z czeską, 3-procentowa rusińska, ale nawet i kilka tysięcy Polaków żyjących w Karpatach), mogła w mniejszym tylko stopniu czerpać z rozwoju gospodarczego. $\mathrm{Z}$ tego powodu ludność z górzystych terenów emigrowała do Ameryki. W latach 1899-1913 Węgry opuściło ok. 1,4 mln osób ${ }^{4}$.

Obok napięć zrodzonych przez spektakularną, ale posiadającą dwa oblicza modernizację, bądź też kłopotów agrarnych związanych z systemem wielkich posiadłości ziemskich, najpoważniejszym problemem była kwestia narodowościowa. Podkreślając swoją tradycyjnie przywódczą rolę, Węgrzy zachowali dla siebie prawo do kierowania państwem (zasada „węgierskiej supremacji”). Węgrzy dominowali w polityce, gospodarce i kulturze. W 1910 r. 84,5\% absolwentów ósmej klasy szkoły średniej uznawało się za Węgrów, 7,8\% - za Niemców, a pozostałe mniejszości etniczne, liczone nawet łącznie, osiągnęły zaledwie ok. 7\%. W miastach w 1910 r. 72\% ludności uznawało się za Węgrów. Na prowincji mieszkał największy odsetek nie-Węgrów, aczkolwiek ok. 60\% majątków ziemskich należała do Węgrów. Przy takich uwarunkowaniach nie było trudno dominować w życiu politycznym i ustanawiać prawa nakierowane na budowanie państwa o węgierskiej kulturze narodowej, przede wszystkim poprzez wprowadzenie obowiązkowego nauczania języka węgierskiego jako języka państwowego ${ }^{5}$.

Węgry miały być państwem zdefiniowanym i określonym przez węgierską kulturę. W sferze publicznej używanie języków ojczystych mniejszości narodowych starano się wyprzeć, w życiu prywatnym tolerowano posługiwanie się tymi językami, oczekując jednak od tych mniejszości politycznej lojalności. Mniejszości miały uczyć się węgierskiego obok własnego języka ojczystego. W praktyce jednak dochodziło do wielu naruszeń ze strony władz ${ }^{6}$.

Mimo występowania różnych form ucisku i ograniczania państwo węgierskie stworzyło dla mniejszości narodowych możliwości równoległego budowania ich

Ibidem.

Ibidem.

Ibidem. 
własnych tożsamości narodowych, bardziej pokojowe niż w większości państw regionu Europy Środkowej i Wschodniej, w szczególności zaś w niemieckiej Rzeszy, a zwłaszcza w Rosji.

\section{Wpływ Traktatu z Trianon na kulturę Węgier}

Traktat zawarty w Trianon postrzegany był od początku jako niesprawiedliwy. Węgry, będąc częścią monarchii habsburskiej, poniosły konsekwencje przegranej wojny, mimo że nie wywołały jej, ponieważ nie prowadziły samodzielnej polityki zagranicznej. Jak już wspomniałem, większa część dawnego Królestwa Węgier zamieszkana była przez narody inne niż węgierski. Niemniej kryteria przyznawania terenów ze względu na kryterium etniczne często okazywały się nieprawdziwe. Np. tereny dzisiejszej południowej Słowacji zostały przyłączone do Czechosłowacji, aby nowe państwo miało więcej pól uprawnych (w wielu miejscowościach do dziś Węgrzy stanowią większość). Podobna sytuacja miała miejsce na terytorium Baczki, które włączono do Królestwa Serbów, Chorwatów i Słoweńców, jak i część Siedmiogrodu oraz Banatu, które znalazły się w Rumunii. Wyjątkiem jest część Burgenlandu, gdzie wokół miasta Sopron odbył się plebiscyt, dzięki czemu obszar ten pozostał przy Węgrzech. Pomógł też zbrojny opór miejscowej ludności, która dopuściła do oddania regionu w ręce austriackie.

Pozytywnie odbierany przez Węgrów polityk francuski Georges Clemenceau zapewniał Węgrów, że rewizja traktatu w oparciu o kryterium etnograficzne i Pakt Ligi Narodów (art. 19 umożliwiał badanie traktatów, które nie daja się już stosować) jest możliwa. Życie pokazało jednak coś innego. Na konsekwencje traktatu nie trzeba było długo czekać. Między 1918 a 1924 r. do Węgier przybyło 400-500 tys. uchodźców z terenów wcześniej odłączonych od państwa. Większość stanowili pracownicy państwowi, miejscy i samorządowi.

Mimo utraty terytorium wcześniej stanowiącego integralną całość pod kątem politycznym, gospodarczym i kulturalnym węgierska gospodarka do połowy lat dwudziestych stanęła na nogi i dostosowała się do swojego nowego środowiska. Wzrost gospodarczy i produkt krajowy brutto w $1928 \mathrm{r}$. przekroczyły poziom $\mathrm{z}$ ostatniego roku pokoju przed wojną.

Niemniej zakres i sposób wymierzonego Węgrom upokorzenia wykluczał zaakceptowanie którejkolwiek $\mathrm{z}$ decyzji terytorialnych traktatu pokojowego. Akceptowalne byłoby pozostawienie w obrębie państwa około półtora miliona Węgrów, żyjących w wąskim pasie wzdłuż nowej granicy w Komárom, Koszycach, Beregszász, Szatmárnémeti, Nagyvárad, Aradzie. „Graniczymy sami ze sobą” -

Ibidem. 
z goryczą mówiono w nowym, kadłubowym państwie ${ }^{8}$. Nowy europejski ład był dla Węgrów klęską i upokorzeniem, a manifestacje pamięci o traktacie trwają od dnia jego podpisania do dziś, pomijając okres komunistyczny, kiedy to nie można było podejmować dyskusji na ten temat.

Już 4 VI 1920 r., w dniu podpisania traktatu, w całym kraju bito w dzwony i odprawiano nabożeństwa żałobne, a gazety ukazały się w czarnych obwódkach; zamknięto szkoły, urzędy i sklepy, na 5 minut stanął transport publiczny, a flagi państwowe opuszczono i pozostawiono je tak do $1938 \mathrm{r}$. W rocznice Trianon żałobę przywdziewał parlament, urzędnicy i miliony obywateli ${ }^{9}$.

Od jesieni 1920 r. węgierscy uczniowie mieli obowiązek odmawiać w szkole narodową modlitwę „Magyar Hiszekegy”, czyli „Węgierskie wyznanie wiary” czterowiersz poetki Elemérné Sziklay Papp-Váry. Czterowiersz znało każde dziecko, a tekst był reprodukowany na niezliczonych plakatach:

\section{Wierze w jednego Boga, \\ Wierzę w jedna ojczyznę, \\ Wierzę w sprawiedliwość niebios, \\ Wierze w zmartwychwstanie Wegier.}

Władze i organizacje społeczne dbały o przestrzeń publiczną. I tak, już pół roku po Trianon, w sercu Budapesztu, na Szabadság tér, wzniesiono Pomnik Niepodległości z niezwykle bogatą symboliką. Cztery figury symbolizowały: Zachód, Północ, Wschód i Południe, a zarazem - wszystkie ziemie zabrane: słowacki chłopiec tulił poranioną ojczyznę, osłaniany przez wąsatego i uzbrojonego kuruca (XVII-wiecznego powstańca); Zachód opierał się na krzyżu św. Stefana, u jego stóp znalazł się turul - mityczny ptak Hunów. Na Wschodzie na wpół legendarny książę Csaba wznosił tarczę z herbami Siedmiogrodu, na południu zaś muskularny Węgier rycersko pomagał Szwabce z Banatu dźwignąć snop zboża ${ }^{10}$. Podobne pomniki powstawały również przy granicach kraju np. w Zebegeny, na naddunajskiej skarpie. Pomnik był świetnie widoczny z Pozsony (obecnie Bratysława). Z kolei w połowie lat 20. rozpoczęto wznoszenie masztów dla flag państwowych (Országzászló Mozgalom), których ustawiono ponad 700. Wszystko po to, by przywoływać traumę Trianon, co najmniej kilka razy w roku: w dniu

8 P. Stachowiak, Sto lat węgierskiej traumy, https://www.przewodnik-katolicki.pl/Archiwum/2020/Przewodnik-Katolicki-17-2020/Historia/Sto-lat-wegierskiej-traumy (20 VII 2020).

9 J. Kochanowski, Wegry. Od ugody do ugody 1867-1990, Warszawa 1997, s. 161-163.

10 W. Stanisławski, Kraj upokorzony, ziemie utracone. Żałoba trwa od stu lat [5 VI 2020], https:// tygodnik.tvp.pl/48362532/kraj-upokorzony-ziemie-utracone-zaloba-trwa-od-stu-lat (20 VI 2020). 
Pamięci Bohaterów w ostatnią niedzielę maja, w rocznicę haniebnego traktatu, w dzień świętego Stefana (20 VIII) i w urodziny regenta Horthy’ego...

Również w dwudziestoleciu międzywojennym narodził się węgierski mesjanizm. Znalazł odbicie w obrazkach, na których Węgry ukazywane były jako Jezus Chrystus, a Trianon jako krzyż. W Sátoraljaújhely z publicznych pieniędzy rozpoczęto na pobliskiej górze Szár (Kis-szárhegy) budowę kalwarii, którą otworzono 4 X 1936 r. Usytuowanie nie było przypadkowe, ponieważ Sátoraljaújhely położone było przy granicy z Czechosłowacją, gdzie w południowej części żyły tysiące Węgrów. Kalwaria węgierska (węg. Magyar Kálvária) składa się z 14 pomników, jak w chrześcijańskich kalwariach, na których upamiętniono 38 miast dawnych Wielkich Węgier. Wysokie na ok. 2,5 metra obeliski miały przypominać utracone miasta dawnego Królestwa Węgier. Na tablicy przy każdej nazwie miejscowości umieszczono cytat znanego Węgra, podkreślający węgierskość danej miejscowości lub jej znaczenie w historii. Wszystkie te działania miały na celu budowanie czy modyfikowanie „post-trianońskiej” tożsamości węgierskiej, służącej dalszej mobilizacji społecznej, co mogło być przydatne w bardziej sprzyjającej koniunkturze politycznej.

W podręcznikach poświęconych geografii, historii, literaturze, a nawet towaroznawstwu były rozdziały poświęcone ziemiom, tradycjom, twórcom i dobrom materialnym, które znalazły się za granicą. Pod koniec lat 30. prawie jedna trzecia tematów prac uczniowskich, szczególnie tych najważniejszych (prace roczne, maturalne, dysertacje studenckie) dotyczyła obszarów utraconych lub dyskusji nad szansami ich odzyskania.

Ważną rolę odegrała rządowa Centrala Związku Organizacji Społecznych TESZK, finansując prawie wszystko, co miało jakikolwiek związek z interesami Węgrów za nowymi granicami kraju. TESZK gromadziła dane, opracowywała zebrane informacje, wspierała węgierskie partie i organizacje za granicą. Ponadto organizacja tworzyła w krajach, w których mieszkała mniejszość węgierska, niezależne stanowiska pracy, aby koordynować węgierską działalność polityczną, gospodarczą i kulturalną. Ponadto prowadziła na Węgrzech internaty dla uczniów z mniejszości węgierskich, wspierała ich organizacje oraz finansowała inicjatywy gospodarcze, udzielała pożyczek, podejmowała gości zagranicznych, utworzyła archiwum prasowe, a także kolekcję książek i druków na temat mniejszości narodowych. Z inicjatywy premiera Pala Telekiego (węgierski polityk, minister wychowania i dwukrotny premier Węgier w latach 1920-1921 oraz 1939-1941) powstał Instytut Nauk Politycznych utworzony w 1926 r. pod egidą Urzędu Statystycznego. Instytut powstał jako ośrodek ekspercki do rewizji traktatu z Trianon. Miał dostarczać informacje politykom, dziennikarzom i badaczom, zajmującym się krajami ościennymi ${ }^{11}$.

11 B. Ablonczy, Pal Teleki (1879-1941), Warszawa 2020, s. 91. 
Olbrzymie znaczenie dla kultury Węgier miało pismo „Nouvelle Revue de Hongarie", powstałe co prawda głównie dla czytelników zagranicznych, ale też wykształconych Węgrów. Pismo nie uprawiało bezpośredniej propagandy, jedynie pojedyncze artykuły dotyczyły rewizji granic lub kwestii terytorium Węgier. W „Nouvelle Revue de Hongarie” kładziono głównie nacisk na ambitną literaturę węgierską, m.in. takich autorów, jak Dezso Kosztolanyi i Mihaly Babits, a oprócz tego - na umiarkowany w tonie przegląd wydarzeń międzynarodowych, specjalistyczne artykuły najlepszych węgierskich ekspertów i teksty autorów francuskich. Na równie wysokim poziomie był „Hungarian Quarterly”. Oba pisma miały oddziaływać na decydentów, a nie na masy. Chodziło o to, aby temat rewizji traktatu odnieść do kontekstu spraw ogólnych, europejskich. Dużą rolę w powstaniu periodyków odegrał Pal Teleki, który był świadom roli czasopiśmiennictwa, przeżywającego wówczas w Europie złoty okres, w kształtowaniu świadomości i przekazywaniu informacji. Oprócz wymienionych periodyków Teleki zaangażował się także w utworzenie „Magyar Szemle” („Przegląd Węgierski”). Tytuły te miały charakter liberalno-konserwatywny. Aż do wojny były użytecznym forum głównie dla polityków oraz inteligencji skupionej wokół Istwana Bethlena ${ }^{12}$.

Traktat z Trianon znalazł odbicie m.in. w twórczości wybitnego węgierskiego pisarza Sandora Maraia. W 1919 r. Géza Marai, ojciec pisarza, przekonał syna do wyjazdu na Zachód, obawiając się jego zaangażowania po stronie rewolucji. Wcześniej Sandor opublikował kilka krótkich artykułów i wierszy w komunistycznej gazecie „Vörös Lobogó” („Czerwony Sztandar”). Przyczyny swojego zaangażowania pisarz opisze później w powieści Buntownicy (A Zendülők). Jest to bunt przeciwko pokoleniu ojca, odpowiedzialnemu, według Sándora, za „utratę" miasta, które na mocy traktatu przekazano Czechosłowacji. Przyjaciel Maraia, pisarz Dezső Kosztolányi, wypowiedział słowa, które przeszły do nowożytnej historii Węgier: „My wszyscy umieramy po trosze na Trianon”. „W pełnej dostojeństwa strukturze Miasta, gdzie każdy jego mieszkaniec znał swoje miejsce i miał poczucie własnej rangi - czy to wytwórca świec, mydlarz, kamieniarz, adwokat (jak ojciec Máraiego), czy burmistrz lub biskup - złamać jeden szczebel w tej drabinie społecznej znaczyło zachwiać całą strukturą. Stanąć przeciwko ojcu znaczyło stanąć przeciwko Miastu. Stanąć przeciwko Miastu znaczyło zakwestionować porządek świata, albowiem Miasto było miniaturą świata"13.

Postanowienia traktatowe znalazły także odbicie w działaniach bardzo dyskusyjnych. I tak np. władze wpłynęły na lotników, Sandora Magyara i György Endresza, by dwupłatowiec, którym w 1931 r. przebyli Atlantyk, nazwać „Sprawiedliwości dla Węgier!’. Podobne gesty były także spontaniczne, odzwierciedlające

12 Ibidem, s. 92.

13 F. Netz, Życie w micie [18 VI 2013], https://www.tygodnikpowszechny.pl/zycie-w-micie-19742 (24 V 2020). 
emocje większości Węgrów, niezależnie od zapatrywań politycznych i pochodzenia. Wiele inicjatyw ocierało się jednak o groteskę. Wspomina się szczególnie mosiężne tabliczki, wieszane zwykle u drzwi wejściowych do mieszkań, z frazą: „Nem! Nem! Soha!” („Nie! Nie! Nigdy! [nie pogodzimy się]”) oraz podwójnym konturem granic Węgier - z roku 1914 i tych po traktacie.

Frazę tę wykorzystał w swoim wierszu największy węgierski liryk pierwszej połowy XX w., Attili Józsefa. Pojawiła się także na kotylionach, flagach, transparentach i plakatach: na jednym $\mathrm{z}$ nich okrwawiony rzeźnik rąbie tasakiem mape „Wielkich Węgier”, a przygląda się temu z przerażeniem chłopiec. W kawiarniach tańczono „patriotyczne fokstroty”, „Nem! Nem! Soha!” malowano na syfonach z wodą sodową, niezbędną do przyrządzenia dobrego szprycera, kontur Węgier wyciskano $\mathrm{w}$ glinie popielniczek. $\mathrm{Z}$ lat 30. pochodzą też statuetki znane jako „Nagymagyarország” („wielkie Węgry”). Ceramiczny, jaskrawoczerwony posążek o kształcie ozdobnej urny na popioły przybranej kwiatami, po odpowiednim podświetleniu rzucał na obrus lub ścianę cień w kształcie przedwojennych granic Węgier ${ }^{14}$.

Dotkliwe postanowienia mocno obciążyły społeczeństwo Węgier zarówno pod względem politycznym, jak i materialnym oraz moralnym. Dlatego głównym celem polityki zagranicznej rządu węgierskiego w okresie międzywojennym była rewizja traktatu, co odpowiadało też nastawieniu opinii publicznej ${ }^{15}$. Los Pála Telekiego, który we wrześniu 1939 r. zdołał jeszcze powiedzieć „nie” Berlinowi, domagającemu się wsparcia podczas kampanii wrześniowej w Polsce, odzwierciedla losy Wegier po Trianon. W kwietniu 1941 r. strzelił sobie w skroń. Była to ostatnia kula wystrzelona w ramach „żałoby trianońskiej”. Równie niezwykłe były inne gesty towarzyszące tej żałobie. Psycholodzy dobrze znają jej dynamikę w przypadku życia indywidualnego: szok, tęsknota, rozpacz, rekonwalescencja. Rzadko jednak zdarza się, by żałoba taka trwała przez pokolenie - a wracała, przynajmniej na poziomie oficjalnych gestów, i po stu latach ${ }^{16}$.

Nie powinno zatem dziwić szukanie różnych dróg rewizji postanowień traktatu. Jedna z nich doprowadziła do zbliżenia $\mathrm{z}$ III Rzeszą. Rewizja granic pod kątem jedności terytorialnej bądź etnicznej doprowadziła bezpośrednio do zmian terytorialnych w latach 1938-1941. Dzięki poparciu III Rzeszy Węgrom udało się zrewidować część postanowień z Trianon. Po pierwszym arbitrażu wiedeńskim w listopadzie 1938 r. Węgry uzyskały kosztem Czechosłowacji południową Słowację. Dnia 14 III 1939 r., po rozpadzie Czechosłowacji, Węgrzy zajęli Karpato-Ukrainę, w wyniku drugiego arbitrażu wiedeńskiego w sierpniu 1940 r. uzyskali od Rumunii północny Siedmiogród. Po ataku na Jugosławię Niemcy przekazali Węgrom

\footnotetext{
W. Stanisławski, op.cit.

M. Zeidler, op.cit., s. 51-54.

Ibidem.
} 
serbską Wojwodinę (Baczkę), słoweńskie Prekmurje oraz chorwackie Baranję i Međimurje. W sumie bezpośrednio przed II wojną światową i w czasie jej trwania wróciły do kraju ziemie zamieszkane przez 2 mln Węgrów, a terytorium powiększyło się do 172 tys. $\mathrm{km}^{2}$. Po tym krótkim antrakcie zmiany terytorialne powiększające terytorium Węgier zostały anulowane w $1947 \mathrm{r}$. przez postanowienia pokoju paryskiego.

W latach 1947-1948 dyktatura komunistyczna włączyła do swojej ideologii elementy węgierskiej tradycji niepodległościowej. Jednak nie chciała zajmować się kręgiem tematycznym wokól traktatu pokojowego z Trianon nie z powodu wrażliwości krajów sąsiednich, ale dlatego, że grzebanie w węgierskiej świadomości narodowej mogłoby wywołać nieprzewidywalne dla władzy reakcje.

\section{Węgry demokratyczne}

Węgrzy podtrzymują tradycję wielkich, przedtrianońskich Węgier. Działania te znajdują odzwierciedlenie w wielu inicjatywach, poczynając od ustawodawczych. Pierwszy premier demokratycznych Węgier, József Antall, rozpoczął łączenie narodu ponad granicami, podobnie jak w latach siedemdziesiątych mówił o tym pisarz emigracyjny Illyés Gyula, który nazwał węgierską literaturę całej Niecki Karpackiej pięcioramienną fletnią (ötágú síp). Chodziło o węgierską literaturę siedmiogrodzką, Górnych Węgier (słowacką), Wojwodiny (Jugosławii), krajową oraz literaturę emigracyjną, o której wówczas nie można było wtedy wspominać (Márai Sándor, Wass Albert, Határ Győző) ${ }^{17}$.

W 1992 r. reaktywowano przedwojenny Światowy Związek Węgrów, mający na celu językową i kulturową współpracę z 5 milionami Węgrów mieszkających poza granicami kraju. Do tego samego posłużyła satelitarna telewizja „Duna”. Aby poprawić sytuację mniejszości węgierskiej, uchwalono w 1993 r. ustawę obejmującą prawo o ulgach i podwójne obywatelstwo. Uchwałą parlamentu w $2010 \mathrm{r}$. przyznano wszystkim Węgrom mieszkającym za granicą możliwość uzyskania węgierskiego obywatelstwa, bez stałego miejsca zamieszkania na Węgrzech (do 2019 r. obywatelstwo otrzymało około 850 tysięcy Węgrów). Parlament postanowił także, iż dzień podpisania dyktatu pokojowego w Trianon (4 VI) stanie się „dniem narodowej solidarności” (a nemzeti összetartozás napja). Trzecią uchwałą opracowaną w niesłychanie krótkim czasie (w ciągu roku) była nowa konstytucja (alaptörvény). W preambule stwierdza się: „My, Członkowie Narodu Węgierskiego, jesteśmy odpowiedzialni za wszystkich Węgrów... przyrzekamy, że będziemy strzec rozdartej na kawałki w wichrach ubiegłego stulecia duchowej

17 K. Sutarski, Trianon - czy zabliźnia się ta otwarta rana Europy?, https://wpolityce.pl/historia/ 504048-tej-tragedii-nie-pojmie-uczuciowo-pojac-zaden-inny-narod (6 VIII 2020). 
jedności naszego narodu”. Preambuła powoływała się na państwo króla Świętego Stefana, które - (w domyśle) jeszcze przez prawie tysiąc następnych lat - obejmowało obszar całej Niecki Karpackiej i które „stało się częścią chrześcijańskiej Europy", zaś chrześcijaństwo (w rozumieniu węgierskim, jako trzech religii: katolicyzmu, kalwinizmu i luteranizmu) jest „spajającą naród” siłą. W spólnotę całego narodu ponad granicami wzmacniało zdanie w paragrafie D: „Republika Węgierska czuje odpowiedzialność za losy Węgrów żyjących poza granicami i popiera pielęgnowanie ich kontaktów z państwem węgierskim". Owe trzy uchwały, mające poparcie większości narodu, nadały nowy impuls do zbliżenia się odsuniętych od siebie części narodu.

Równolegle parlament przegłosował ustawę o prawach mniejszości narodowych i etnicznych, zapewniającą możliwość tworzenia samorządów mniejszościowych, w tym ogólnokrajowych, wspartych opieką materialną. Powstał także rządowy Narodowy i Etniczny Mniejszościowy Urząd dla kontaktów i współpracy z żyjącymi na Węgrzech trzynastoma - tradycyjnymi - narodowościami (m.in. cygańską, niemiecką, słowacką, chorwacką, rumuńską - a także i polską). Od 2014 r. poszczególne narodowości mogą także posiadać rzeczników parlamentarnych. Ma być to wskazówką dla krajów ościennych, jak postępować z mniejszością węgierską. Poza tym, dzięki odrębnym traktatom, dążono do poprawy stosunków bilateralnych z sąsiadami.

Od 2010 r. coraz bardziej zwiększa się pomoc materialna dla Węgrów całej Niecki Karpackiej. Fundusze służą rozwojowi oświaty poprzez budowę czy rozbudowę uniwersytetów, szkół, przedszkoli. Organizacje kościelne otrzymują fundusze na odnowę kościołów, węgierskie organizacje sportowe na rozbudowę stadionów, małe i średnie przedsiębiorstwa dostają fundusze na unowocześnianie technologiczne (w tym i bezzwrotne zapomogi), a także skutecznie mogą uczestniczyć w ogólnowęgierskich przetargach przemysłowych, a tamtejsza węgierska młodzież może kształcić się na węgierskich uniwersytetach, by po powrocie służyć zdobytą wiedzą miejscowej ludności ${ }^{18}$.

W listopadzie 2019 r. na budapeszteńskim spotkaniu przywódców węgierskich mniejszości (MÁÉRT-u) premier Viktor Orban podkreślił, iż „bez rozwoju zagranicznych regionów gospodarczych nie jest możliwa węgierska przyszłość tych terenów... zaś sąsiedzi Węgrów muszą zrozumieć, że wzmacnianie narodowe i gospodarcze naszego kraju nie stanowi dla nich zagrożenia. Jest to stwarzanie możliwości, by kraje Europy Środkowej były coraz bardziej dostrzegalne w kręgach wspólnoty europejskiej” 19 .

18 K. Sutarski, op.cit.

19 Ibidem. 


\section{Zakończenie - Trianon wiecznie żywy}

Tak więc podpisany 100 lat temu Traktat w Trianon nie traci na swojej aktualności i wpływa na życie we wszystkich aspektach, począwszy od politycznego, a skończywszy na kulturalnym. Mimo uzasadnionej wrażliwości Polaków na własną historię i jej konsekwencje, jak np. utracone ziemie na Wschodzie, zaskakująca jest siła oddziaływania skutków traktatu na mentalność i decyzje współczesnych Węgrów. W 2008 r., w kolejną rocznicę w Budapeszcie otwarto Park Trianon, upamiętniający ziemie utracone w wyniku traktatu. Najważniejszym elementem znajdującym się w parku jest dzwon, który codziennie, o godz. 16:32, przypomina traktat $\mathrm{z}$ Trianon.

W tym roku, w 100 rocznicę traktatu prezydent Węgier Janos Ader na uroczystym posiedzeniu parlamentu powiedział, że „duchowe granice narodu” pozostały niezmienne, pomimo że zmieniły się granice geograficzne.

Zapewnił, że Węgry nie będą partnerem w przemilczeniach, w fałszowaniu historii i wyrzekaniu się Węgrów mieszkających poza granicami Węgier, będą natomiast partnerem w szczerej rozmowie, wykorzystywaniu historycznych szans oraz wzmacnianiu więzów między Węgrami oraz między nimi a innymi narodami. „Musimy naprawić to, co zepsuły mocarstwa. Jeśli to zrobimy, zdejmiemy z siebie klątwę Trianon" - oznajmił ${ }^{20}$. Węgierskie Muzeum Narodowe udostępniło w Internecie wystawę fotografii przedstawiających bogactwo kulturalne obszarów utraconych w wyniku Traktatu z Trianon. Muzeum Sztuk Pięknych i Węgierska Galeria Narodowa pokazały online najpiękniejsze pejzaże Kotliny Panońskiej autorstwa węgierskich malarzy. W Keszthely mieszkańcy ułożyli z 600 zniczy kontur dawnego terytorium Królestwa Węgierskiego.

\section{Postscriptum}

W Siedmiogrodzie spotkać można Węgrów, noszących koszulki z napisem: „Nie jestem turystą, jestem Węgrem”. Literkę H otoczoną konturem, nieco przypominającym skorupę żółwia, zobaczyć można w domach, sklepach, urzędach, z tyłu samochodów. Niektórzy tatuują go sobie nawet w widocznych miejscach. Węgier, zapytany o ten symbol, odpowie: „Trianon” lub powie: „Nem, nem, soha” („Nie, nie, przenigdy") ${ }^{21}$.

\footnotetext{
20 Węgierski naród nie tylko byt, ale ii będzie [4 VI 2020], https://serwisy.gazetaprawna.pl/prezydencja/artykuly/1481370,traktat-w-trianon-wegry.html (20 VI 2020).

21 P. Stachowiak, Sto lat wegierskiej traumy, https://www.przewodnik-katolicki.pl/Archiwum/2020/Przewodnik-Katolicki-17-2020/Historia/Sto-lat-wegierskiej-traumy (20 VII 2020).
} 


\section{Abstract \\ Kazimierz Serwin \\ Perception of the Treaty of Trianon in Hungarian culture}

The "Trianon" is perhaps the most famous historical term in Hungary. 100 years ago, on June 4, 1920, restrictive peace conditions were imposed on Hungary at the Grand Trianon Palace in Versailles. Apart of the loss of territory, 3,5 million Hungarians remained abroad. In Hungarian historical awareness, the Treaty of Trianon is a symbol of catastrophe and national humiliation. The change of "Greater Hungary" into „small” Hungary. To this day, the effects of the treaty have had an impact on Hungary's politics, economy and culture.

Keywords: treaty, Trianon, culture, injustice, minority, memory, unity, limits, compensation

\section{References}

Ablonczy, B., Pal Teleki (1879-1941), Warszawa 2020.

Ablonczy, B., Po stu latach, https://kurier.plus/node/1427.

Berteny, I. jr, Monarchia Austro-Wegierska, „W sieci historii” 2020, nr 5-6.

Kochanowski, J., Wegry. Od ugody do ugody 1867-1990, Warszawa 1997.

Netz, F., Życie w micie, https://www.tygodnikpowszechny.pl/zycie-w-micie-19742. Stachowiak, P., Sto lat wegierskiej traumy, https://www.przewodnik-katolicki.pl/ Archiwum/2020/Przewodnik-Katolicki-17-2020/Historia/Sto-lat-wegierskiej-traumy.

Stanisławski, W., Kraj upokorzony, ziemie utracone. Żałoba trwa od stu lat, https:// tygodnik.tvp.pl/48362532/kraj-upokorzony-ziemie-utracone-zaloba-trwaod-stu-lat.

Sutarski, K., Trianon - czy zabliźnia się ta otwarta rana Europy?, https://wpolityce. $\mathrm{pl} /$ historia/504048-tej-tragedii-nie-pojmie-uczuciowo-pojac-zaden-inny-narod. Zeidler, M., Traktat pokojowy w Trianon $z 1920$ r., „W sieci historii” 2020, nr 5-6.

Kazimierz Serwin - mgr filologii polskiej, dziennikarz Polskiego Radia Wrocław, członek Towarzystwa Polsko-Węgierskiego im. ks. Mieczysława Woronieckiego we Wrocławiu 